\title{
Comparison of survey data on wealth in Switzerland
}

\author{
Laura Ravazzini (University of Neuchâtel, University of Lausanne) \\ Ursina Kuhn (FORS) \\ Gaël Brulé (University of Neuchâtel) \\ Christian Suter (University of Neuchâtel)
}

Abstract

Beyond income, wealth is one of most relevant components among national and international indicators of household finances. Three surveys that include Switzerland have recently integrated questions about wealth and its components. These surveys are the Swiss Household Panel -SHP- (2016), the Statistics on Income and Living Conditions CH-SILC- (2015), and the Survey on Health, Ageing and Retirement in Europe -SHARE(2015). Following three important criteria suggested by the Organisation for Economic Cooperation and Development (OECD), namely relevance, coherence and accuracy, this study systematically compares data on housing and financial wealth. The analysis addresses question wording, the comparison with national accounts and accuracy. Results suggest that SHARE is the most relevant survey in terms of financial wealth and total net worth. CH-SILC is a coherent survey that allows for additional analysis on subjective living conditions, while the SHP is an ecological survey in terms of the number of questions on wealth.

JEL codes: C81 C83 D31

Keywords: wealth, survey data, real estate, financial assets, data quality This study has been funded by the SNSF-DACH Project (n. 10001AL_166319 / 1) titled « La distribution de la fortune en Suisse et en Allemagne : évidence de données d'enquête ». 


\section{Introduction}

Wealth has many different functions that go beyond the utility derived from it as an income source. It can, for instance, guarantee financial security, augment the social status of individuals and give access to political power and occupational opportunities otherwise difficult to reach (1). Wealth cannot only be used by the current generation as a mobile (e.g. bank accounts) or immobile (e.g. real estates) resource, but it can also be transmitted from one generation to another. In the life-course of individuals, wealth can therefore serve different purposes and affect both the objective and the subjective conditions of individuals.

Empirical data on wealth have been scarce for a long time. Nowadays, data on wealth can be found in two formats: population surveys and tax records, and both have their advantages and disadvantages. Although tax records present an excellent data source to study historical trends of wealth inequality and top wealth shares (2), they have important shortcomings. They notably have no information on the lowest part of the wealth distribution and important wealth components are not covered (e.g. social security wealth, private pension accounts, some wealth abroad) or might be undervalued or undeclared (e.g. value of cars, real estate and consumer credits). Moreover, the taxable value of real estate properties is usually inferior to their market value. ${ }^{1}$

Even more importantly, the analytical potential of tax data is limited because it is not possible to relate wealth to other variables, such as many socio-economic characteristics, life satisfaction or health, and information about investment decisions, such as risk aversion or psychological factors (e.g. the big-five concept of personality). With tax register data it is therefore impossible to study important questions such as the relationship between happiness and money. Moreover, in some countries, tax units do not always correspond with households. Individuals living in cohabiting couples, but not legally married or in a recognized partnership are for instance considered as two separate tax units even if they are part of the same household.

Survey data with information on wealth enable the joint observation of wealth, household characteristics and subjective indicators over one or more point in time. Data on wealth appeared in large survey data in different years depending on the country. ${ }^{2}$ In 2002, for instance, two longitudinal surveys, namely the German Socio-Economic Panel (SOEP) and the Household of Income and Labour

\footnotetext{
${ }^{1}$ In the Swiss case, the difference depends on the cantonal legislation: in each canton, taxes on real estate are estimated every $10-15$ years between the 70 and the $100 \%$ of their market value. Foellmi and Martinez found that Swiss National Bank data, which include real estate properties since 1998, show the same time-trend as tax data. 3. Foellmi R, Martínez IZ. Volatile top income shares in Switzerland? Reassessing the evolution between 1981 and 2010. Review of Economics and Statistics. 2017;99(5):793-809.

${ }^{2}$ Some examples are the Italian Survey on Household Income and Wealth (which collects data on housing wealth and valuables since 1977, data on financial assets since 1987 and data on debt and liabilities since 1991), the American Survey of Consumer Finances (SCF) (which over-samples wealthy individuals since 1989), and the Swiss Household Budget Survey (HBS) (which provides information since 1998 about the historical market value of real estate properties).
} 
Dynamics in Australia (HILDA) included questions about household wealth for the first time. Over the years, the German SOEP refined its questions on wealth allowing to analyse not only the level of household wealth, but also its distribution within household members. The increasing interest on wealth data stimulated efforts to make data comparable across countries and in 2007 the pilot of the Luxembourg Wealth Study (LWS) was launched (4). Some years later, data collection on wealth in the Euro area continued through the creation of the Household Finance and Consumption Survey (HFCS) and the OECD reacted creating guidelines on how to set up data collection on wealth $(5,6)$.

Because wealth has been included only recently into population surveys, the consequences on data quality of how data is collected in different surveys remain largely unknown. In this study, we look at data quality of wealth collected by survey in Switzerland. The study of wealth in Switzerland is interesting because of its high level of median wealth per capita and its high level of inequality (according to tax register data analysed by the Credit Suisse Research Institute (2016) (7), the median wealth in Switzerland is the highest in the world and amounts to USD 244,000; wealth inequality is also high $(3,8)$. Currently, there are several large surveys produced by different data providers that include wealth in this country. Among these, the Swiss Federal Statistical Office included two pioneering modules on wealth in the Statistics on Income and Living Conditions (CH-SILC) 2011 and 2015. Recommendations about how to collect information on wealth have been transmitted to Eurostat for the implementation of similar questionnaires in 12 European countries taking part in EU-SILC 2017. ${ }^{3}$ Switzerland is therefore the first country to have implemented such a questionnaire in SILC and comparable data are being tested at the European level.

The fact that Switzerland has different surveys with questions on wealth collected at the same time gives the unique opportunity to be able to identify the difference linked to survey characteristics than to national contexts.

To assess the impact of survey characteristics, we compare wealth data across three widely used surveys: the CH-SILC, the Swiss Household Panel (SHP), and the Survey of Health, Ageing and Retirement in Europe (SHARE). Not only are we interested in total wealth, but also in housing wealth, financial wealth and within financial wealth, private pension wealth more in detail. All these components are surveyed at different levels of details by CH-SILC, SHARE and the SHP. Housing wealth is currently the largest wealth component even in Switzerland where home ownership is relatively low. Furthermore, primary home wealth is a particular component and it cannot be easily liquefiable (for a distinction between mobile and immobile wealth see Table 1 of (9)). For this reason, primary home wealth is often considered as a separate component in empirical analyses on wealth (e.g. in the estimation of poverty based on income and wealth, see (10)). Financial wealth is a rather classical component of wealth and it is often present in surveys in a reduced form of savings. On average,

\footnotetext{
3 These countries are Belgium, Czech Republic, Finland (sub-sampling), Iceland, Italy, Latvia (sub-sampling), Lithuania, Netherlands, Austria (partly), Portugal (sub-sampling), Sweden, and the United Kingdom.
} 
housing wealth and financial wealth are the two major wealth components and we analyse them more in detail. Contrarily to these two components, very little is known about the third pillar because it is not clearly identified neither in national accounts nor in tax records.

This paper is structured as follows. We start by giving some general information about the three surveys used for the comparison. We continue by presenting the guidelines to measure data quality. We perform the evaluation of wealth and its components according to the OECD guidelines on micro statistics on household wealth $(5,6)$. Among the criteria defining data quality, three are relevant for comparison between surveys within the same country namely relevance, coherence and accuracy. In terms of relevance, we compare the questions on wealth in their latest versions of CH-SILC, SHARE and the SHP. In terms of external coherence, we evaluate the data with respect to tax statistics at the national level. Finally, in terms of accuracy, we analyse how accurate wealth statistics are in the three surveys including information about non-response and imputation of missing data. The results of this analysis are then presented for several age groups comparing means and deciles. We conclude with final remarks and suggestions on how to collect and handle data on wealth and its components.

\section{Three databases on wealth}

We rely on three databases that contain information about wealth in Switzerland: SHARE 2015, the SHP 2016 and CH-SILC 2015. ${ }^{4}$ SHARE is an academically driven survey at the European level on health and ageing. The sample does not cover the entire population, but only households where at least one of the respondents is aged at least 50 at the time where the questionnaire is given. Except for a few modules concerning finances, family or household questions that are answered only by the designated financial, family or household respondent, the questionnaire is usually submitted both to the main respondent and to his/her partner. The panel started in 2004 and collected information about wealth in each wave except from 2008/2009. ${ }^{5}$ Given its panel structure, SHARE suffers from attrition and benefits from learning effects of participants.

The SHP is also a panel survey. It started in 1999 with an individual and a household questionnaire on a yearly basis. Refreshment samples were introduced in 2004 and 2013. This survey is part of a set of the Cross-National Equivalent File (the CNEF). ${ }^{6}$ The SHP contains categorical information about wealth in 2009 and 2010 and continuous information about home wealth and other wealth in 2012 and 2016.

\footnotetext{
${ }^{4}$ SHARE 6.0.0 release of 31.03.2017; SHP data release in 2017; CH-SILC 2015: preliminary version of wealth data of 07.06.2018.

${ }^{5}$ Each wave is annual, but in many countries data collection was performed in between two years in wave 1,2 and 3.

${ }^{6}$ The Swiss Household Panel (SHP) is part of the Cross-National Equivalent Files (CNEF). Among the CNEF, there are also the German Socio-Economic Panel (SOEP), the Household Income and Labour situation in Australia (HILDA), Understanding society about the UK and the PSID in the USA that collect information on wealth. Given
} 
The last survey we use, $\mathrm{CH}$-SILC, is a 4-year rotating household panel available for Switzerland since 2007. In CH-SILC, data on income refer to the preceding year, while data on wealth refer either to the current time or the end of the preceding year. ${ }^{7}$ Although data are collected with some lags in the three surveys, there are several similarities that make the surveys comparable. All of them rely on a random sample of the permanent resident population stratified over seven macro regions. Regarding CH-SILC and the SHP, the survey mode is CATI (Computer-Assisted Telephone Interviewing) with some exceptions for particular cases. The survey mode of SHARE is CAPI (Computer-Assisted Personal Interviewing). Personal interviews are necessary for SHARE because the respondents might be asked to execute physical tests and to sample their biomarkers. ${ }^{8}$

None of these surveys perform an oversampling of top wealth holders. Another similarity is that they all impute missing values for income and wealth.

\section{Measuring data quality}

The OECD proposes seven criteria to evaluate quality of wealth data (OECD, 2013a, 2013b). These seven criteria are a. Institutional environment, b. Relevance, c. Coherence, d. Timeliness, e. Accessibility, f. Comparability, and g. Accuracy. This set of criteria has been used by Tiefensee and Grabka (12) to assess the quality of the HFCS by comparing the surveys in the different Euro-countries. The aim our paper differs in some respects. As we do not compare surveys in different countries, but surveys within the same country, the institutional environment (a) and data accessibility (e) are more similar than in international surveys. According to the OECD, institutions should be "adequately resourced to produce the statistics of interest". The surveys reviewed here have been collected either by FORS (SHARE and the SHP) or by the Swiss Federal Statistical Office (SFSO) (CH-SILC), which are both experienced, professional and equipped with the necessary resources for data collection and evaluation. Moreover, all surveys are based on the same sampling frame. FORS is a publicly funded foundation for the research in social sciences that distributes all databases free of charge for research purposes. The SFSO distributes plausibilised and imputed data to researchers placing different prices to data releases according to the survey required and the project in which the data will be used. This process of data plausibilisation, integration of register data, imputation and weighting calculation

the difference in the questions on wealth, only very limited comparability is possible between the SHP and the other household surveys listed above (see Ravazzini and Kuhn for a short introduction of the wealth variables used in the SHP, SOEP and HILDA).

11. Ravazzini L, Kuhn U. Wealth, Savings and Children Among Swiss, German and Australian Families. In: Tillman R, Voorpostel M, Farago P, editors. Social Dynamics in Swiss Society. Cham: Springer; 2018. p. 161-74.

${ }^{7}$ From the French CH-SILC questionnaire: Une estimation grossière suffit au moment de l'interview ou en fin (année-1).

${ }^{8}$ Exceptions to CAPI are the drop off questionnaires on which the respondent can work in private, when it is most convenient for them and the vignettes questionnaires which are conducted via paper and pencil. Another exception are end-of-life interviews, which can be conducted via CATI. 
takes time and creates longer waiting times between the completion of fieldwork and the release of the data. Data on wealth are publicly available for SHARE and the SHP, but not for SILC. In this last case, data have to be obtained upon special agreements. Timeliness (d) is an important aspect for crossnational data which should compare countries at the same point in time. The different surveys were not designed to be comparable or to refer to the same point in time, but their periods of data collection are somewhat similar. Differences in timeliness might therefore help to understand the divergence of certain results, but they are not a criterion for this analysis because the period 2014-2016 was characterised by stable economic conditions in Switzerland. In addition to this, cross-country comparability (f) is not part of the relevant criteria for this analysis, but comparability between different waves of the same survey is presented in the first part of the analysis. To assess the data quality of the different surveys in Switzerland, namely relevance (b), coherence (c), and accuracy (g), are important. This paper focuses therefore on a comparison of national surveys according to their relevance for the measurement of wealth, their external coherence compared with national tax records and their accuracy in connection with imputed values. These concepts are explained in detail in the following dedicated sections.

\section{Relevance}

Relevance is defined by the OECD as the "degree to which statistics meet the needs of actual and potential users [...] thus it depends upon coverage of the required topics and the use of appropriate definitions or concepts" ((6), p. 193). To evaluate relevance, we assess to what extent the survey questions by the SHP, CH-SILC and SHARE are in line with guidelines and concepts of the OECD. In the first part, we focus on questions about housing, financial wealth and more particularly private pension wealth (Table 1). In the second part, we mention the other wealth components collected in the three surveys (Table 2).

\section{(Table 1 about here)}

We first discuss the similarities and differences between the three surveys for housing wealth in more detail. A similarity between CH-SILC and SHARE is that they collect information on the value of the house and on mortgages with two separate questions. The SHP is different in this respect as only one question is asked. People have to estimate the value of their house and at the same time subtract possible mortgages. The number of questions on wealth is crucial because on the one hand, people might for instance forget about a small mortgage if the question is not specifically asked, but on the other hand, too many questions might induce item non-response. Surveys that ask only a general question about wealth are expected to suffer from underreporting and biases as respondents have to make more computations, whereas surveys that ask too many questions are expected to suffer from a high percentage of missing data. Some surveys distinguish primary residences from other residences 
and some ask separate questions for market values and mortgages. $\mathrm{CH}-\mathrm{SILC}$ does not distinguish between primary and secondary residences and asks a question about mortgages on all real estate assets. ${ }^{9}$ SHARE asks two separate questions about the market value of the primary residence and other real estate assets and only one question about mortgages on the primary residence. This survey does not collect information on mortgages on secondary residences, which might however be important depending on the tax system of the country. The choice to combine or separate primary and secondary residences in the questionnaire has important implications for the imputation because these surveys contain many information on the primary residence (size, year of construction, environment), but much less on the secondary residence. For this reason, only ownership, housing costs and imputed rents, but not house characteristics are used in SILC for the imputation of missing values. In the SHP, other real estate is included in another more general question on other wealth net of debt. It is therefore impossible to estimate the total amount of mortgages or the value of secondary properties from this survey.

The third column of Table 1 indicates that the surveys vary also with respect of the type of value of a real estate property. Even if difficult to acquire, the OECD suggests using current market values to estimate housing wealth. While SHARE and the SHP follow this guideline, CH-SILC 2015 allows respondents to indicate the estimated current market value, the historical market value, the taxable value and the insurance value. Almost $50 \%$ of respondents tend to indicate the current market value, as suggested by the survey, and as second choice, the purchase price (19.3\% of respondents) or the taxable value (14.8\% of respondents) (see Figure 1 ).

To better understand the choice of the type of value by respondents, we run multinomial logistic regressions on basic socio-demographic characteristics of the respondent. We find that variables associated with indicating the current market value are being a man, active on the labour market, higheducational level, living in urban areas and in large houses. Young people and inactive, low-educated women living in rural areas and in small houses prefer to report the purchase price.

The fact that the value choice is not random shows that it might reduce selective item non-response compared to a questionnaire that asks only about the current market value. However, the lack of conversion scales makes it hard to reach a common current market value for all the respondents reporting housing wealth. The conversions are not straight forward but rely on assumptions or rules of thumb. Purchase price and insurance price might be considered equal because in case of accidents, insurance companies reimbursed the replacement value of the insured object, which is often an adjustment of its purchasing price excluding the value of the land. ${ }^{10}$

\footnotetext{
${ }^{9}$ In CH-SILC, we know whether people have other real estate than the first residence, but we do not know the wealth associated with each housing component.

${ }^{10}$ The conditions for the estimation of the replacement value depend on the insurance policy. Even if people might ask for a re-evaluation of their house over time, we assume that most of the respondents know the
} 
(Figure 1 about here)

To convert these values to their current market values, we perform an adjustment with the real estate market price published by the Swiss National Bank for Swiss macro areas. ${ }^{11}$ We use the year during which people bought their house for the purchasing price and the year in which people bought or moved in their current house for the insurance value. ${ }^{12}$

The taxable value is also rather complex to convert as the tax legislations vary from canton to canton and depend on the type of object subjected to the property tax. ${ }^{13}$ We apply approximate conversion rates between the taxable value and the current market price based on the Swiss National Tax Conference. ${ }^{14}$ No conversion is applied to the mixed estimate.

These adjustments are particularly important for the insurance value, which goes from a mean of 446,746 to 785,646 CHF (the median value goes from 256,500 to 380,386 CHF) (Figure 2). The variability of the estimates is here increased by correcting for the year in which people bought their house or moved there. These adjustments are important also for the purchase price, which goes from a mean value of $344,829 \mathrm{CHF}$ without adjustments to $505,901 \mathrm{CHF}$ after the adjustment (the median value goes from 225,000 to $289,858 \mathrm{CHF}$ ) and for the taxable value, which goes from a mean of 368,076

insurance value of their house according to the evaluation made when they bought their house. For this reason, the insurance value given by respondents should equal the purchasing price minus the value of the land.

${ }^{11}$ Data come from this website:

https://data.snb.ch/en/topics/uvo\#!/cube/plimoinreg?fromDate=1970andtoDate=2015anddimSel=DO(EW,EH, $\mathrm{MW}, \mathrm{BF}, \mathrm{GF}), \mathrm{D} 1(\mathrm{GS}, \mathrm{RZ}, \mathrm{RO}, \mathrm{RI}, \mathrm{RN}, \mathrm{RBO}, \mathrm{RS}, \mathrm{RGO}, \mathrm{RW}, \mathrm{RB} 1, \mathrm{RG} 1, \mathrm{US})$.

In these data, the seven macro-regions of Switzerland are represented expect for Mittlelland, which is constructed averaging the price corrections of Bern and Western Switzerland. The time trend starts in 1970. Only $1.5 \%$ of houses reported in SILC were bought before that year. We adjust for prices of single-family houses and of residential apartments. Prices of non-residential real estate are not corrected as we do not know their position or their nature (e.g. commercial or living space, land, etc.).

${ }^{12}$ Respondents who chose the insurance value were not asked about the year in which they bought their house, but another variable allows to estimate when they bought or moved in their current residence. This question is asked to all respondents independently from their tenure status.

${ }^{13}$ In most cantons, a distinction is made between farming properties and land and other real estate. The difference between these taxable values can be large (e.g. in the canton of Bern, land can be taxed between the $10 \%$ and the $65 \%$ of its current market value; in Neuchâtel, people can indicate the $70 \%$ of the purchase price of real estate, whereas in Geneva the taxable value for primary residences declines with the number of years people live in their primary residence (- $4 \%$ per year up to a maximum of 10 years); in Vaud, the taxable value represents around $80 \%$ of the purchase price). From an investigation across cantonal legislations, we estimate that the conversion rate should be between 60 and $90 \%$.

${ }^{14}$ The information can be found in:

http://www.steuerkonferenz.ch/downloads/kreisschreiben/KS 22 Repartitionsfaktoren F final 20180629.pdf We approximate the values by regions weighted by their population. We reweight the cantons to obtain $60 \%$ for the lowest taxable values and $90 \%$ for the highest taxable values. With these adjustments we obtain $77 \%$ for Geneva and the lake, $88 \%$ for the Mittelland, $82 \%$ for the Northwest, $69 \%$ for Zurich, $69 \%$ for the East, $72 \%$ for the centre and $90 \%$ for Ticino. 
to a mean of $485,510 \mathrm{CHF}$ (median from 225,000 to $280,682 \mathrm{CHF}$ ). These adjustments therefore correct for the possible downward bias of these reported values.

(Figure 2 about here)

Financial wealth represents the second wealth component. We compare its measurement across surveys, which also reveals important differences (see Table 1). Two questions are asked in CH-SILC: one about the balance of bank or post accounts and one about the total value of bonds, stocks and mutual funds. SHARE is more precise because it includes all investment funds beyond mutual funds, ${ }^{15}$ and specifies stocks or shares as listed or unlisted on the stock market, bonds from the government or from corporates, and bank and post accounts also in the form of clearing or saving accounts. Savings in SHARE are further detailed with a question about contractual saving for housing ("épargnelogement" in French), which is not a very widespread form of saving in Switzerland, but some cantons (Basel land, Zug, Genève and Obwalden) encourage home ownership through contractual saving for housing and tax deductions (13). SHARE has also a question about the value of own business, which is complemented by a question about the share of this business owned by the respondent. This high level of detail corresponds to a higher number of questions (six in total) and a higher burden for respondents. Compared to the other two surveys, the SHP is, as in the case of housing wealth, the most ecological because only one question asks whether people have other wealth including other real estate and financial wealth (the items savings, stocks and bonds are directly mentioned in the question). This formulation of the question makes it impossible to distinguish financial wealth from other forms of wealth.

The third wealth component is private pension wealth. In the SHP questionnaire, people are asked to exclude from the amount of non-housing wealth the amount related to second and third pillar funds. The amounts linked to the second and third pillars are not covered by other questions, but a question asks whether someone in the household saves in a third pillar pension plan. The questionnaires of $\mathrm{CH}$ SILC and SHARE ask directly about the amount linked to private pension plans. Most of the questions are addressed to the individual than to the household. CH-SILC introduced the question on the current value of the third pillar in 2015. ${ }^{16}$ Respondents who do not know the current value are asked how much they think they will withdraw from their third pillar accounts. Among those who declared to have a third pillar but did not answer to the amount, $22.5 \%$ answered to the question about expected withdrawals. This last question was not used for imputation of third pillar funds. In CH-SILC, people without a third pillar are also asked whether they do not have a third pillar for financial reasons. The

\footnotetext{
${ }^{15}$ Other investment funds can be exchange-traded funds, money market funds and hedge funds.

${ }^{16}$ The question includes saving and private pension plans, life insurance and sickness and accidents insurance, with or without tax privileges.
} 
question about the third pillar is also asked differently according to whether the respondent is employed or self-employed. In case of self-employed, the question asks also about the presence of a second pillar, which is not mandatory for this professional category. The question about the amount asked in the third pillar excludes all possible second pillars. ${ }^{17}$ Employed individuals are not asked about their second pillar. In SHARE, questions about the third pillar are highly detailed and there are a few additional questions compared to CH-SILC. An additional question in SHARE concerns life insurance policies. In SILC the questions about third pillar accounts is rather generic, while in SHARE, respondents have to detail their answers according to the type of saving they own. The face value asked in this question on life insurance policies is linked to an additional question on the nature of the third pillar. The question is: "are these individual retirement accounts mostly in stocks or mostly in bonds?". Respondents need to have a rather advanced financial knowledge to be able to answer to these specific questions.

Table 2 shows a summary of wealth measurement by components in the different surveys. Even if all these three surveys provide a measure of total net worth ${ }^{18}$, the composition of this estimate differs according to the survey. We compare the information provided in each survey with the OECD guidelines.

As far as real estate is concerned, surveys should identify wealth linked to the principal residence, to other owner-occupied dwellings and to other real estate ((6), p.67). The same distinction should be made for mortgages. Based on this list, none of these three surveys comply with the OECD guidelines. In terms of housing wealth and other real estate, the SHP can identify only primary home wealth net of mortgages, CH-SILC can identify total housing wealth, but not primary home wealth and SHARE can identify primary home wealth and other real estate, but it does not include questions on mortgages on other real estates than primary homes.

In terms of financial wealth, the OECD recommends identifying five items: currency and deposits, bonds and other debt securities, (corporate) shares and other equity, mutual funds and other investment funds, net equity in own unincorporated business. The SHP does not identify any of these components, CH-SILC identifies four out of five items at least partly, whereas SHARE identifies all items and sometimes with a superior level of details than what is specified in the OECD guidelines. In SHARE, a slightly lower level of detail is asked about equity in own business as respondents do not have to specify whether their business (company or firm) is incorporated or not. Moreover, none of these surveys ask about currency or cash, but this should constitute a very low amount in European countries where savings are usually accumulated within the banking system. Currency should be particularly

${ }^{17}$ From the French CH-SILC instructions to interviewers: « Le 2ème pilier pour les indépendants est facultatif. Retenir les piliers 3a (par ex. compte épargne prévoyance $3 \mathrm{~A}$ ) et les piliers $3 \mathrm{~b}$ (assurance risque décès, assurance vie avec épargne; avec ou sans privilèges fiscaux). Les biens immobiliers ( $p$. ex. Maison) ne sont pas comptés comme 3ème pilier. "

${ }^{18}$ Total net worth is identified as assets minus debts. 
negligible in Switzerland given the general trust people have in the national banking system. Therefore, both CH-SILC and SHARE ask about deposits, but only SHARE satisfies the level of detail asked for other financial wealth. Even if SHARE includes questions about all the items required by the OECD guidelines, the high level of detail about financial wealth asked in this survey may overburden respondents, who might be also somewhat more distant from the financial system than working-aged respondents.

In terms of pension funds, even if all surveys ask a question about private pension wealth, only $\mathrm{CH}$ SILC and SHARE can identify the amount. According to the OECD standards for measuring household wealth, it should be possible to identify both social insurance pension funds, which are pensions and other benefits from employment-related social insurance and therefore the I and the II pillar in the Swiss pension system, and private pension funds, which correspond to the III pillar in the Swiss pension system. Although both CH-SILC and SHARE can be linked with administrative records about social insurance pension funds in Switzerland, these data are not yet publicly available. ${ }^{19}$

Differences between surveys continue with the number of wealth components collected by each survey. As previously illustrated in Table 1, the most ecological survey in terms of questions about wealth is the SHP, whereas the most detailed survey is SHARE. CH-SILC is rather in between as it allows for some aggregations, but it also expands some relevant questions that are in line with one of the primary aim of the survey, namely living conditions. Moreover, CH-SILC can identify the total amount for valuable objects (e.g. jewellery and art) and cars, whereas SHARE can identify only car wealth and no other consumer durable. None of these surveys can distinguish consumer durables from valuables or can identify intellectual property as suggested by the $\operatorname{OECD}((6)$, p.69). Compared to its 2011 version, however, CH-SILC 2015 does not contain any indications about liabilities other than mortgages. This is because SILC surveys indebtedness in special modules and in 2015, the wealth and the indebtedness modules did not coincide. ${ }^{20}$ One of the values added of SHARE in comparison to other surveys is that it can identify liabilities other than mortgages. Compared to the OECD guidelines, none of these surveys provides the expected level of detail, which should allow for the distinction of wealth linked to vehicles, other consumer durables, valuables, intellectual property and other non-financial assets. The OECD guidelines have also rather high standards for loans as they ask for the distinction between financial asset loans, valuable loans, intellectual property and other non-financial asset loans, vehicle loans, other consumer durable loans, education loans, other loans and liabilities. SHARE asks whether respondents have loans on vehicles, exceeded credit cards limits, financial loans, loans with friends or relatives, student loans and unpaid bills. The question about the amount of these loans is then grouped

\footnotetext{
19 Part of this project is working on data linkage between $\mathrm{CH}-\mathrm{SILC}$ and administrative records about public pensions. Other countries of SHARE (Germany and Denmark) have made a data linkage through an informed consent and this information is now available for users.

${ }^{20}$ From SILC 2011, we know that the mean value of non-housing liabilities is $254 \mathrm{CHF}$ and the median is $0 \mathrm{CHF}$. Although the maximum value can be $144,000 \mathrm{CHF}$, at least $95 \%$ of the population does not have debts and the underestimation produced on net worth by the lack of this component should not be extremely high.
} 
and this makes it is impossible to know the exact amount for each of these items if the respondent has more than one form of debt. This might be a strategic choice of this survey as the number of questions about financial assets and debts is already quite high. In CH-SILC, only the special module on indebtedness in SILC might be able to provide this high level of detail regarding these items. ${ }^{21}$ To summarize the relevance of the surveys in terms of the OECD guidelines, SHARE seems to be the most precise with respect to financial assets. Improvements could however be made within real assets and liabilities. The most important omission is information on mortgages for secondary residences. CH-SILC collects the most important wealth components of household wealth, but for most components, it is not as detailed as suggested in the OECD guidelines. The most important omission relevant for net worth are questions on liabilities. The SHP is the least accurate survey with respect to household wealth components.

\section{Coherence}

Coherence is defined as the adequacy of the data to be reliably combined in different ways and for different uses. Internal coherence is hard to test with questions on wealth as it should be cross-checked by other questions of the same questionnaire. For example, debt and liabilities could be cross-checked with questions on material deprivation or on issues related to the payment of unforeseen expenditures or regular bills. In addition, income from wealth and the subjective evaluation of not having problems to pay bills should be coherent with measures of positive wealth accumulated by individuals. Even if not impossible to test, internal coherence would require many assumptions. External coherence can be more easily tested as is it represents the coherence with external sources of information, such as Swiss National Accounts (SNA) or the population census. In this analysis, we use national accounts as reference. Given that national accounts provide only aggregates for the overall population, we do not compute the coherence for SHARE as this survey covers only the population from 50 years of age and older and would not be comparable by default. We therefore focus on CH-SILC and the SHP.

Net worth in SNA comprises currency and deposits, debt securities, shares, units in collective investments schemes, structured products, insurance and pension schemes, loans (mortgages, consumer loans, other loans) and other payable accounts (14).

The financial assets of households consist of currency and deposits, investment in securities, and insurance and pension schemes. For the comparability between surveys and SNA, it is important to remark that SNA do allow to identify private pension wealth but include information about both the second and the third pillar. In SNA, insurance and pension schemes are essentially made up of life insurance and occupational pension entitlements. In the case of insurance and pension schemes,

\footnotetext{
${ }^{21}$ In 2020, a new European module of SILC will include indebtedness, consumption and wealth. This module will give more complete information about the material well-being of households.
} 
investment income is taken into account in addition to paid premiums and pension fund contributions and withdrawals. The third pillar is not mentioned as a component, but it is disaggregated into life insurances held in insurance and pension schemes, and other forms of savings (probably) held in the deposits. Business assets other than shares are not mentioned in SNA and are accounted only in the balance sheets of corporations.

To compare households between surveys and SNA, it is also important to notice that data on the financial assets held by households, which are derived from the Swiss financial accounts ${ }^{22}$, comprise the financial assets and liabilities of non-profit institutions serving households (NPISHs), such as relief organisations, churches, trade unions, political parties and recreational clubs. The financial assets and liabilities of NPISHs account for roughly $2-3 \%$ of total financial assets and liabilities (14). Data on the real estate assets do not include the real estate of NPISHs.

To compare the external validity of housing wealth, it is important to understand how estimates in the SNA are derived. Data on real estate assets are estimated by the Swiss National Bank (SNB). This estimate is based on an evaluation of the dwellings recorded in the National Register of Buildings and Dwellings (RBD) issued by the Swiss Federal Statistical Office. The real estate assets reported comprise single-family homes, owner-occupied apartments and apartment buildings with rental apartments located in Switzerland - including the land belonging to the buildings. These three standard properties are evaluated by real estate consulting companies using hedonic pricing models. This is done for each municipality in Switzerland. The prices obtained in this manner are multiplied by the number of properties in each municipality. Adding the totals for all municipalities provides an estimate of the market value of all single-family homes, all owner-occupied apartments and all apartment buildings with rental apartments in Switzerland. Finally, the share of the households sector in the overall stock of each of the three property types is estimated, using a reference value taken from the Swiss Housing Census of 2000. The same data source is used to divide up the residential stock into owner-occupied and rental dwellings. The Housing Census has to be used because the requisite information is not available in the RBD. Commercial real estate, undeveloped land and real estate abroad are not covered. National accounts are also not able to distinguish real estate held by individuals living abroad from domestic holding.

We now compare SNA and CH-SILC, the SHP in terms of real estate assets, mortgages and net housing wealth without a distinction of primary home wealth. We can also compare total net worth if we exclude the second pillar from SNA. Data are not top-coded. Table 3 illustrates how CH-SILC data on housing wealth corresponds to the national aggregate of the corresponding year (we remind that wealth collected by CH-SILC might refer to the moment of the interview or to the previous year). Positive housing wealth adjusted for the value chosen in CH-SILC is $107 \%$ of the national aggregate.

${ }^{22}$ The Swiss financial accounts form part of the national accounts for Switzerland (see www.snb.ch, Statistics, Statistical publications, Swiss Financial Accounts). 
This difference is probably linked to the approximation by macro regions made in the adjustment of housing wealth to current market value, which might have had a heterogenous price evolution at the cantonal or municipal level. Without the adjustment to current market value, however, mean positive housing wealth would be 204,448 CHF and therefore $93 \%$ of national accounts. In both cases, adjusted or not, there is a very high correspondence between positive housing wealth in CH-SILC 2015 and in SNA. ${ }^{23}$ This high correspondence might be given by the high coherence of home ownership of this survey compared to the Swiss structural survey (38.7\% in Ch-SILC 2015 compared to 38.2\% of the Swiss structural survey; for CH-SILC 2014 see the quality report of the SFSO (16), p. 54).

Housing wealth in CH-SILC 2015 is rather coherent with national accounts. Mortgages are 88\% of SNA, ${ }^{24}$ whereas net housing wealth is $119 \%$ of SNA. Housing wealth is overestimated also in the SHP, but to a much larger extent ( $144 \%$ of the national account). There are several possible reasons for the overestimation of housing wealth in the SHP. A first possibility is the selectivity of the sample (underrepresentation of recently immigrated foreigners). Moreover, $52.4 \%$ of the interviewed households report to be homeowners. Applying cross-sectional weights (household level), the rate of homeowners in the SHP 2016 amounts to 45.5\% and is therefore still too high. Once we calibrate the household weights so that they match official homeownership rates, the average housing wealth in the SHP amounts to 165,951 CHF or $125 \%$ of national accounts. Therefore, the overestimation of homeownership rates is not the only responsible for the overestimation of housing wealth. A second reason for this overestimation might be the difficult question wording. In the same question, respondents have to estimate the market value, estimate mortgages, and compute the difference between the two amounts within the same question. The way of questioning makes it impossible to identify whether current market values are overestimated, mortgages are underestimated, or the calculation is not accurate. A third reason for the overestimation of housing values are outliers. 8 households reported a value of their primary residence of 100 million CHF or higher, which are likely to be measurement errors. If we top-code these households to the 99.75 centile (or 4 million CHF), average net housing wealth in Switzerland amounts to 158,983 CHF or $120 \%$ of the SNA. The SHP data has not been edited apart from imputing non-response. The application of a form of top-coding and adjustment of weights to the share of property owners is thus recommended.

In SILC, the comparison with financial assets shows also a good level of coherence. We compare the aggregate of currency and deposits, debt securities, shares and other equity in SNA with the aggregate of deposits, stocks, bonds and mutual funds and the third pillar in SILC. External coherence for this

\footnotetext{
${ }^{23}$ This ratio was estimated to be only $44.8 \%$ in CH-SILC 2011 according to Ecoplan. 15. Ecoplan. Vermögenslage der privaten Haushalte. Vermögensdefinitionen, Datenlage und Datenqualität. Neuchâtel: Swiss Federal Statistical Office, 2014. In 2011, however, a filter error excluded housing wealth of primary homeowners who did not have additional real estate assets. This filter is likely to have contributed to the difference between CH-SILC 2011 and 2015

${ }^{24}$ Among people with positive housing wealth in $\mathrm{CH}-\mathrm{SILC}, 86 \%$ have a mortgage.
} 
component is $75 \%$ in $\mathrm{CH}-\mathrm{SILC}$. Total net worth is coherent at $92 \%$ in $\mathrm{CH}-\mathrm{SILC}$ and at $138 \%$ in the SHP. We can thus conclude that CH-SILC is more coherent than the SHP with respect to both net housing wealth and total net worth.

\section{(Table 3 about here)}

We test external coherence also in terms of representativity of very wealthy individuals, which are often not sampled by survey data. We present the estimates of total net worth according to CH-SILC and the SHP to see how far the maximum of the two surveys is distant from the maximum of the wealth distribution among very wealthy individuals in Switzerland according to the magazine Bilanz (17). We use the magazine Bilanz because, contrarily to Forbes, Bilanz has the advantage of surveying very wealthy individuals depending on their place of residence and not their nationality. At the top of the 300 very wealthy individuals listed by Bilanz in 2017, the richest family has 48.5 billion Swiss francs and is followed by the second richest with 28.5 billion Swiss francs. From the $282^{\text {nd }}$ position, wealth is reported to be around 125 million, which is relatively close to the maximum reported by CH-SILC (121 million) and by the SHP (106 million). We remind that these surveys do not use any top-code even if CH-SILC made plausibility checks. In the top of the distribution at the top, we remark that at the $99 \%$ does not have more than three million Swiss francs in CH-SILC and not more than four million francs in the SHP (Table 4). The distance between the $99 \%$ and the maximum is therefore rather large in these surveys. The distance becomes even larger if we consider the $95 \%$ or the $90 \%$, whose values remain below one million francs. In the two surveys, the share of the top $10 \%$ corresponds to $60 \%$ of the total wealth surveyed by CH-SILC and to $69 \%$ of the total wealth surveyed by the SHP. For the top $5 \%$, the share goes down to $46 \%$ in CH-SILC and $57 \%$ in the SHP. Finally, the share is $23 \%$ with CH-SILC and $37 \%$ with the SHP for the top $1 \%{ }^{25}$

The large difference between the $99 \%$ and the top extreme of the distribution move the average wealth measured by these surveys far beyond its median value. As is known from the tax-records and from Bilanz data, wealth data is truly highly skewed and top wealth is underestimated with surveys. Nevertheless, outliers in surveys might also be due to measurement error. The application of topcoding is thus a delicate task. Applying a top-code to the wealth variables will depend on the aim of the empirical analysis that researchers want to perform. A top-code will make these surveys more representative of the middle class, but less representative of very wealth respondents. Extreme values might also have a different weight depending on the wealth component that researchers want to analyse. We deal with this issue in the next section.

(Table 4 about here)

\footnotetext{
25 These measures suggest a high level of inequality and it is indeed the case if we measure it through the Gini index. In a scale from 0 to 1, inequality of net worth is 0.748 in CH-SILC 2015.
} 


\section{Accuracy}

Accuracy refers to the degree to which the data correctly allow estimation of the population characteristics they are designed to describe.

We analyse accuracy with descriptive statistics across surveys and with analyses of non-response. We analyse non-response because it might be linked to the number and the details in the questions asked by the surveys. To evaluate the distribution, we first plot means by age groups with CH-SILC, SHARE and the SHP.

\section{Descriptive statistics}

We provide mean values to have a simple comparison of what it is often reported as the only information about household wealth. Nevertheless, the potential impact of outliers on mean values should be kept in mind. Therefore, we continue the analysis by going beyond mean values evaluating also different percentiles of the distribution though bar or box plots.

In the descriptive statistics, we start with housing wealth and private pension wealth and we continue with financial wealth and total net worth. To facilitate the comparison, we start with a comparison of total housing wealth in CH-SILC and SHARE according to different age groups defined by the household head. ${ }^{26}$ We create wealth per-capita by dividing household wealth by the household size and assigning this wealth to the household head. Figure 3 shows that CH-SILC gives a higher mean value for people $65+$, but the two surveys are relatively close in terms of positive housing wealth for the age group 5064. Given that CH-SILC is rather coherent with respect to housing wealth, also SHARE is likely to be highly coherent with respect to this wealth source. The picture changes when we analyse mortgages. Mortgages in SHARE are much lower than in CH-SILC, which are already underestimated compared to NA. This is probably because there is no question about mortgages on secondary residences and other real estates. Mortgages are therefore likely to be underestimated in an important way in SHARE and consequently net housing worth is likely to be overestimated. A closer look at the distribution by percentiles (see the graph on net home and housing wealth among home owners 50+ of Figure 3 ) shows that this bias is persistent all along the distribution until the 95 percentile. This underestimation of mortgages might be country-dependent and in some countries might constitute a minor difference, but this is not the case of Switzerland, where mortgages on secondary residences and other real estates are important. We can therefore conclude that the measure of net housing wealth in SILC data is less biased by mortgages than the measure of net housing wealth in SHARE. ${ }^{27}$

\footnotetext{
${ }^{26}$ We define the household head as the person with the highest income and in case of parity as the eldest person. ${ }^{27}$ The proportion of people with negative or 0 housing wealth is slightly different between the two surveys (41\% among people aged 50-64 and 39\% among people aged 65+ in CH-SILC, and respectively $30 \%$ and $36 \%$ in SHARE). This difference might be due to mortgages.
} 
(Figure 3 about here)

We now add the SHP to the picture. For this comparison, SHP data have been top coded at the 99.75 percentile or 4 Mio Swiss francs, to exclude the influence of outliers and the age distribution. Weights have been adjusted to match the share of home owners as discussed above. We first compare it with net housing wealth of the other two surveys and then to home wealth linked to primary home wealth in SHARE. Theoretically, we should underestimate net housing wealth in the SHP because this survey measures only the value of the primary residence. We indeed find a strong underestimation for people above 50 years old (left panel of Figure 3). If we then compare only net home wealth for the primary residence in SHARE and the SHP, we discover that home wealth remains slightly underestimated in the SHP (right panel of Figure 4).

(Figure 4 about here)

After evaluating household wealth, we move to the evaluation of other wealth components. In Figure 5 , we can notice that the importance of financial wealth and especially stocks, bonds and mutual funds is highly comparable. The amount linked to third pillar accounts increases up to 64 years old and then declines as soon as people enter retirement age. This is due to the proportion of people owning a third pillar account, which, according to SILC, starts at $60 \%$ among people between 25 and 39 years old, goes up to $69 \%$ among people between 40 and 64 years old and then declines to $13 \%$ among people $65+{ }^{28}$ Between people aged 50-64 and 65+, bonds, stocks and mutual funds increase almost as much as the decline in third pillar accounts. In SILC, 34\% of people between 50 and 64 own this form of financial wealth, whereas $44 \%$ of people aged $65+$ have it. The same trend can be observed in SHARE, where $34 \%$ of the people between 50 and 64 own this form of financial wealth, whereas $42 \%$ of people aged $65+$ have it. This means that an important share of the third pillar is likely to be converted in stocks, bonds and mutual funds after retirement. Deposits in the form of bank accounts or other savings are more different between the two surveys. Wealth in the form of deposits is two times larger in CH-SILC than in SHARE for people between 50 and 64 and three times larger for people 65 and more. Given that Figure 4 shows only mean values, this difference might be linked to outliers. The proportion of people without any deposits is also slightly different in the two surveys: $9 \%$ among people $50+$ in SILC and $2 \%$ in SHARE. In CH-SILC, median values of deposits for people aged 50-64 is 16,024 and 45,000 for people $65+$, roughly similar estimates than the mean values obtained with SHARE. Therefore, some

\footnotetext{
${ }^{28}$ The third pillar can be withdrawn at the retirement age and maximum 5 years after that age if people continue working.
} 
outliers might drive high means in deposits in CH-SILC. Another reason for high wealth in deposits could be the instructions written in the CH-SILC questionnaire.

Even if people are asked to declare only the bank accounts and other accounts that are not part of the third pillar, when people are asked about the amount they have in these accounts, the instruction to exclude 3rd pillar accounts is not repeated. It could be therefore possible that people declare the total amount they have in their account including also the third pillar.

(Figure 5 about here)

This last hypothesis is however not able to explain why deposits are so large also for people aged $65+$. It is therefore more likely that high averages are driven by outliers and we suggest using a top-coding for this wealth component in CH-SILC. Even if this top coding is likely to reduce data coherence, it will improve the balance between the different wealth components surveyed by $\mathrm{CH}-\mathrm{SILC}$. The distribution of the wealth components displayed in Figure 5 for the population $50+$ in $\mathrm{CH}-\mathrm{SILC}$ can be observed also in Figure 6. Even if the distribution appears rather condensed, ${ }^{29}$ Figure 5 helps to understand the importance of observations at the top of the wealth distribution. ${ }^{30}$

From Figure 6 we can see that, by construction, adjusted net housing wealth is the only component that can have negative values. All the other components start at 0 . The mean and the median values of net housing wealth differ due to the high number of observations that exceed the $75 \%$ of the distribution. For the age group of the $50+$, the median is $87,500 \mathrm{CHF}$, while the mean is three times larger: 261,743 CHF. In addition, $0.5 \%$ of the sample (45 observations in CH-SILC and 9 observations in SHARE) go past the arbitrary threshold of 3 million CHF reaching a maximum of 30.5 million Swiss francs. For this component, the percentage of people above 3 million $\mathrm{CHF}$ in SHARE is the same of $\mathrm{CH}$ SILC. In CH-SILC, the difference between the mean value and the median value is however larger for other wealth components.

(Figure 6 about here)

Figure 6 shows that there is a big difference between surveys in the upper part of the distribution of deposits. In CH-SILC, the median value of deposits is $25,000 \mathrm{CHF}$, while the mean value is almost four

\footnotetext{
${ }^{29}$ An alternative representation of the distribution is provided through distribution curves and Lorenz curves in Figures $A 1$ and $A 2$. In all these representations, we use untransformed values. In empirical applications based on wealth, many researchers use the inverse hyperbolic sine transformation to make wealth more normally distributed (see 18. Pence KM. The Role of Wealth Transformations: An Application to Estimating the Effect of Tax Incentives on Saving. The BE Journal of Economic Analysis \& Policy. 2006;5(1):1-26. And 19. Killewald A, Pfeffer FT, Schachner JN. Wealth inequality and accumulation. Annual review of sociology. 2017;43:379-404.)

${ }^{30}$ Figures with all values and with values used for the box plots are available in Figure A3.
} 
times larger (96,313 CHF). In SHARE, the mean for this component is only two times larger than the median (median=15,799 CHF vs. mean=38,214 CHF). Even if the difference between these two surveys remains also in terms of median values, the largest difference is clearly in terms of mean values. In $\mathrm{CH}$ SILC, deposits have six observations above the threshold of 3 million CHF reaching a maximum of 120 million CHF. It is important to remark that in SHARE, there are no individuals with deposits beyond 3 million CHF due to top-coding. The maximum of 120 million CHF for savings is likely to be an outlier, but, as we have seen in the section on coherence, there are about 300 people in Switzerland with at least this amount of wealth. Therefore, even if a top-coding could reduce the influence of outliers, it will also reduce coherence and the representativity of very wealthy individuals. In a comparison between two American surveys, Pfeffer et al. (20) found that in the wealth distribution the largest differences between two are in the top 1-2 percent of the distribution. If data are not top-coded, this holds also for Swiss databases. In our surveys, top values are important also for stocks, bonds and mutual funds. Due to large number of people without these wealth components, the median values of stocks, bonds and mutual funds is 0 . Stocks, bonds and mutual funds exceed the threshold of 3 million francs with 12 values up to 12 million CHF in CH-SILC and SHARE has 9 values beyond this threshold. The influence of top values is lower for the third pillar. While the median value of the third pillar is also 0 , this component remains below this threshold of 2 million francs both in CH-SILC and SHARE.

Non-response

Non-response differs between unit non-response (UNR) and item non-response (INR). UNR happens when the unit (the interviewee) refuses to answer to the entire questionnaire, whereas INR represents the refusal or incapacity to answer to particular questions. INR might happen for several reasons. Some questions might be judged, for instance, too personal to be answered, whereas others might require too much effort to find the correct information (e.g. questions linked to specific components or special insurances that need particular documentation). UNR is corrected through weighting, whereas INR is corrected through imputations. In this section, we analyse INR. With a set of 16 socio-demographic variables that might influence INR, ${ }^{31}$ we find that in terms of $R$ squared, only $8.5 \%$ of the INR of housing wealth in CH-SILC, $5.2 \%$ of the INR of housing wealth in SHARE $7.9 \%$ in the SHP are explained. We can therefore conclude that non-response is not selective on observables in these surveys. An additional comparison of subsequent waves with the SHP and SHARE suggests also that panels tend to lose those respondents with item-non-response by attrition. In these surveys, attrition is not significantly related to the value of the house.

\footnotetext{
${ }^{31}$ These variables are age, activity status, civil status, education, household size, number of children, citizenship, household income, degree of urbanization of the place of residence, interest in sport, volunteering and political activity, trust in others, subjective health, number of rooms of the house, year when the house was bought.
} 
Apart from INR, SHARE trims the data at the extremes. SHARE imputes the top and bottom $2 \%$ of the distribution and implausible values. CH-SILC does not trim extreme observations but makes plausibilisation tests on the variables about household wealth. The SHP does not implement any top coding or plausibilisation tests. In this survey, missing values are therefore attributable exclusively to INR or UNR. In SHARE, we know whether the amount has been imputed because of complete INR, because the answer was not precise and belonged to a bracket of values, or because the value exceeded predetermined thresholds. The thresholds set by SHARE 2015 for housing wealth are 15 million $\mathrm{CHF}$ for the value of the house and 10 million $\mathrm{CHF}$ for both other real estate and mortgages. The imputation procedure in SHARE is slightly more complex than in SILC and in the SHP. Consequently, imputed values for net housing wealth constitute a higher percentage in SHARE (24\%) than in CH-SILC (10\%). In the SHP $2015,23 \%$ of all household did not indicate their net housing wealth., CH-SILC has still considerably lower non-response rates for the same age groups due to refusals or "don't knows" than SHARE (7 p.p. lower excluding data trimming) and the SHP (13 p.p. lower). For financial wealth components, INR is $9 \%$ for the third pillar in CH-SILC, $28 \%$ in SHARE, $19 \%$ for deposits in SILC, 33\% in SHARE, and $5 \%$ for bonds stocks and mutual funds in SILC, and 13\% in SHARE.

For total net worth, if the respondents do not answer to a particular component in CH-SILC 2015, they are asked to indicate where their total wealth is situated within a range of six possible values (e.g. less than 10,000; from 10,000 to 50,000; from 50,000 to 100,000; ...; more than 1 million Swiss francs). This range option in CH-SILC 2015 refers to total net worth, whereas the SHP and SHARE ${ }^{32}$ apply this option for each wealth component asked in the questionnaire. The non-response for total net worth is $33 \%$ in CH-SILC, $62 \%$ in SHARE and $29 \%$ in the SHP.

Although it is difficult to judge the precision of imputations, we can conclude that imputations in SHARE are based on more information, but CH-SILC imputes fewer cases. The imputation procedure of SILC has been recently revised. Imputations with the SHP are documented by Kuhn and Crettaz (21), whereas the documentation about SHARE is available through several documents (22-24). Both the SHP and SHARE use multiple imputation techniques. In SHARE this is done cross-sectionally by country and sample type (singles and 3rd respondents, couples with both partners interviewed, and all couples - with and without non-responding partners). Panel imputation is not used in SHARE due to break in the sequence of wealth estimations linked to wave 3 (SHARELIFE). The imputation procedure in SHARE was revised in the release 5.0.0 $(24,25)$ and since then, lagged variables are no longer used in the imputation. Despite these revisions, in panel data, imputations can still cause uncongeniality issues, i.e. the imputation model can be less general than the model used to analyse the imputed longitudinal data (26). Therefore, a more general imputation model is planned in the future releases of SHARE. In

\footnotetext{
32 The SHP proposes ten possible options (e.g. 1 to less than 50,000; from 50,000 to less than 75,000; from 75,000 to less than 100,000; ...; more than 1,000,000 Swiss francs), whereas in SHARE there are three different entry points for an unfolding bracket sequence. The interviewer then asks: "Is the value a) more than this amount, b) less than this amount or c) approximately this amount?".
} 
all releases, SHARE provides five imputed values for each missing one, i.e., with five different complete datasets that differ from one another only with respect to the imputed values. For this analysis we chose the first value. The SHP and CH-SILC provide only one imputed value for each missing observation. The first value of the multiple imputation is standardly provided. In the SHP, wealth and longitudinal information in 2012 are included in the imputation model.

In addition to the usual socio-demographic variables, the imputation of wealth in CH-SILC uses register data about household income of the last 20 years and imputed rents and social aid from other questions of CH-SILC. In CH-SILC 2015, imputed values can range between the first and the $99^{\text {th }}$ percentile, whereas in CH-SILC 2011 the imputation range was the $10^{\text {th }}$ and the $90^{\text {th }}$ percentiles. The new imputation procedure has therefore enlarged the variability of the data. The new imputation procedure concerns all household variable on wealth and therefore has no effect on the third pillar, which is measured at the individual level. The third pillar follows old plausibilisation and imputation rules. The last report on the quality of cross-sectional data is available on the website of the SFSO for CH-SILC 2014 (16). The software used for the imputation of income and wealth is IVEWare: Imputation and Variance Estimation Software, developed by the Researchers at the Survey Methodology Program, Survey Research Center, Institute for Social Research, University of Michigan. This software builds multiple imputation based on multivariate regressions. No report is currently available about the quality of imputation of wealth variables. The methodology for data imputation on wealth is currently being revised to test a nearest neighbour algorithm.

\section{Conclusions}

After an extensive use of tax register data, the introduction of questions on wealth in survey data has led to several surveys that measure wealth variables. Between 2014 and 2016, in Switzerland, three main surveys measured wealth, namely CH-SILC, SHARE and the SHP. Following the OECD guidelines on data production on wealth, we evaluated these surveys in terms of relevance, coherence and accuracy.

We focussed particularly on housing wealth, private pension wealth and financial wealth. The level of details of these three components changes according to the survey.

We found that SHARE is the most relevant and complete survey in terms of questions on housing wealth, private pension wealth and financial wealth. Questions on private pension wealth and financial wealth are particularly detailed, whereas housing wealth lacks an important question about mortgages on secondary residences and other real estates. In Switzerland, this missing question creates an underestimation of mortgages and an overestimation of total net housing wealth. SHARE is also the survey that measures the highest number of wealth components without suffering from selective nonresponse biases. 
The second most relevant survey is CH-SILC, which comes with the limitations of not including liabilities and not being able to distinguish wealth linked to primary or secondary residences. In terms of financial wealth, CH-SILC can identify stocks, bonds or mutual funds and the third pillar. Other financial assets, such as life insurances and business assets, are not covered by this survey. CH-SILC has however a very good coherence with national accounts for total housing wealth and for total net worth suggesting high data quality. CH-SILC has also some additional questions that other surveys do not ask. CH-SILC asks whether people do not have a third pillar for financial reasons, which is an important question for the measurement of poverty and deprivation. Moreover, CH-SILC allows for the value choice of housing wealth. On the one hand, this value choice option might be responsible for high response rates, but on the other hand, it makes it difficult to convert all values into homogeneous current market values of housing wealth among respondents. If this question is provided also in the next data collection about wealth, a conversion factor should be provided. Further questions should also be made between the year in which people bought their first residence and other real estate. In addition to this, a way to improve the lack of liabilities could be to impute them assuming full INR. As it is now, the survey assumes zero liabilities other than mortgages. Data imputation could be a solution to this problem.

The last survey in terms of relevance is the SHP. This survey is ecological in terms of number of questions on wealth. The SHP asks only two questions about primary home wealth and other wealth to homeowners and only one question on total wealth to tenants. Housing wealth is overestimated in this survey. Calibration of the cross-sectional survey weights to the official rates of homeownership can reduce, but not eliminate this bias.

After this assessment, we can conclude that there is a trade-off between the quality of questions and the questionnaire length. Depending on the main purpose of the survey, different strategies for collecting wealth information has been applied. SHARE is much more interested in economic variables than CH-SILC or the SHP and its focus on the elderly makes wealth particularly important. It is however not to underestimate the potential use of wealth in CH-SILC and in future EU-SILC as this survey is often used to construct composite indices of quality of life and deprivation indices based on different resources. Even though the extension of the wealth variables is limited in the SHP, the richness of question of this survey makes it particularly suitable for different empirical applications that test the association between these wealth variables and attitudinal values. The panel nature of this survey and the fact that it covers the entire population make this survey also particularly interesting for the study of the change in wealth over the life course. Future panel waves will allow for these types of study also in Switzerland.

In all the surveys we analysed, there are still some improvements that could be implemented. One of these improvements could be the inclusion of a measure of augmented wealth. Even if all these surveys ask questions about the third pillar, none of them is able to estimate an accurate measure of 
augmented wealth, which is net worth augmented with pension entitlements $(27,28)$. The issue concerns mainly the estimation of the second pillar, which depends on the employment and marital history of individuals. In SHARE, this issue has been solved by some countries though data linkage with administrative data (e.g. SHARE-RV for Germany and REGLINK-SHAREDK for Denmark). In the SOEP, questions on pension wealth have been included in the questionnaire. Empirical analysis of this data seems reassuring in terms of the ability of respondents to provide this information (27). A new project is currently linking CH-SILC and administrative data to produce a measure of augmented wealth also in Switzerland. Another solution would be asking directly for a specific question about second pillar accounts.

Another improvement could be the disaggregation of housing and total wealth at the individual instead of the household level. These improvements will allow for gender-based research and for the study of differences in living conditions during the life-course of individuals.

Finally, very wealthy individuals are either not properly covered by these surveys or refuse to answer for confidentiality reasons. Adjusting weighting for unit non-response for these respondents would solve the issue of refusal. Another solution would be to oversample very wealthy individuals to improve coverage, a solution already implemented by the German SOEP. In our surveys, we have also seen that extreme values are responsible for high average values. This issue is particularly important in the surveys that do not apply a top-code, namely in the SHP for housing wealth and in CH-SILC for financial wealth. For analyses on the middle class, the decision to top-code the extremes of the distribution of deposits in CH-SILC seems rather sensitive. Moreover, for the SHP, a top-code at the 99.75\% helps in the comparability with the other surveys. Alternatively, the SHP could also construct weights according to the Swiss structural survey. The decision to top-code will however make data less coherent with national accounts and less representative of very wealthy individuals. Independently from the decision that researchers take when they analyse the data, we agree with the conclusions recently proposed in the Annual Review of Sociology (19) about the need to go beyond mean and median values and to show the entire range of values of total net worth and its components. 


\section{References}

1. Orr AJ. Black-white differences in achievement: The importance of wealth. Sociology of education. 2003;76(4):281-304.

2. Piketty T. Capital in the Twenty-first Century. Cambridge: Harvard University Press; 2014.

3. Foellmi R, Martínez IZ. Volatile top income shares in Switzerland? Reassessing the evolution between 1981 and 2010. Review of Economics and Statistics. 2017;99(5):793-809.

4. Jäntti M, Sierminska EM, Van Kerm P. Modeling the joint distribution of income and wealth. Measurement of Poverty, Deprivation, and Economic Mobility: Emerald Group Publishing Limited; 2015. p. 301-27.

5. OECD. OECD framework for statistics on the distribution of household income, consumption and wealth. Paris: OECD Publishing; 2013.

6. OECD. OECD Guidelines for Micro Statistics on Household Wealth. Paris: OECD Publishing; 2013.

7. CreditSuisseResearchInstitute. Global Wealth Databook 2016. Zurich: Credit Suisse Research Institute, 2016.

8. Suter C, Ravazzini L. Ungleichheit in der Schweiz. Bern: SAGW Bulletin, 2018.

9. Brulé G, Ravazzini L. The four forms of wealth and happiness: how different forms of wealth affect the subjective well-being of the elderly in Europe. In: Brulé G, Suter C, editors. Wealth(s) and Subjective Well-Being? Cham: Springer; 2019.

10.Kuypers S, Marx I. Estimation of joint income-wealth poverty: A sensitivity analysis. Social Indicators Research. 2018;136(1):117-37.

11.Ravazzini L, Kuhn U. Wealth, Savings and Children Among Swiss, German and Australian Families. In: Tillman R, Voorpostel M, Farago P, editors. Social Dynamics in Swiss Society. Cham: Springer; 2018. p. 161-74.

12.Tiefensee A, Grabka M. Comparing wealth-data quality of the HFCS. Survey Research Methods. 2014;10(2):119-42.

13.Delbiaggio K, Wanzenried G. Bausparen: Eine ökonometrische Wirkungsanalyse kantonaler Bausparmodellen. Bern: Office fédéral du logement OFL, 2009.

14.SNB. Patrimoine des ménages en 2014. Zurich: Swiss National Bank, 2015.

15.Ecoplan. Vermögenslage der privaten Haushalte. Vermögensdefinitionen, Datenlage und Datenqualität. Neuchâtel: Swiss Federal Statistical Office, 2014.

16.SFSO. Rapport sur la Qualité selon les données transversales EU-SILC 2014 Suisse. Neuchâtel: Swiss Federal Statistical Office, 2017.

17.Bilanz. 300 Reichste 2017. Bilanz. 2018.

18.Pence KM. The Role of Wealth Transformations: An Application to Estimating the Effect of Tax Incentives on Saving. The BE Journal of Economic Analysis \& Policy. 2006;5(1):1-26.

19. Killewald A, Pfeffer FT, Schachner JN. Wealth inequality and accumulation. Annual review of sociology. 2017;43:379-404. 
20.Pfeffer FT, Schoeni RF, Kennickell A, Andreski P. Measuring wealth and wealth inequality: Comparing two US surveys. Journal of economic and social measurement. 2016;41(2):103-20.

21.Kuhn U, Crettaz E. Wealth variables in the Swiss Household Panel: Imputation and first results. SHP Working Paper 1_15 [Internet]. 2015 04/12/2018. Available from: https://forscenter.ch/projects/swiss-household-panel/scientific-activities/.

22.Börsch-Supan A, Jürges H. The survey of health, aging, and retirement in Europe-Methodology. Munich: MEA, MaxPlanckInstitute for Social Law and Social Policy, 2005.

23.Christelis D. Imputation of Missing Data in Waves 1 and 2 of SHARE. SHARE Working Paper Series 01-2011 [Internet]. 2011 04/12/2018. Available from: http://www.shareproject.org/uploads/tx sharepublications/WP Series 01-2011 Christelis.pdf.

24. Malter F, Börsch-Supan A. SHARE Wave 4: Innovations and Methodology. Munich: MEA, Max Planck Institute for Social Law and Social Policy, 2013.

25. Malter F, Börsch-Supan A. SHARE Wave 5: Innovations and Methodology. Munich: MEA, Max Planck Institute for Social Law and Social Policy, 2015.

26.Meng X-L. Multiple-imputation inferences with uncongenial sources of input. Statistical Science. 1994;9(4):538-58.

27.Bönke T, Grabka M, Schröder C, Wolff EN. A Head-to-Head Comparison of Augmented Wealth in Germany and the United States. National Bureau of Economic Research, 2017.

28. Wolff EN, Marley M. Long-term trends in US wealth inequality: methodological issues and results. The measurement of saving, investment, and wealth. Chicago: University of Chicago Press; 1989. p. 765-844. 
Figure 1: Proportion of respondents according to value choice for housing wealth in CH-SILC 2015

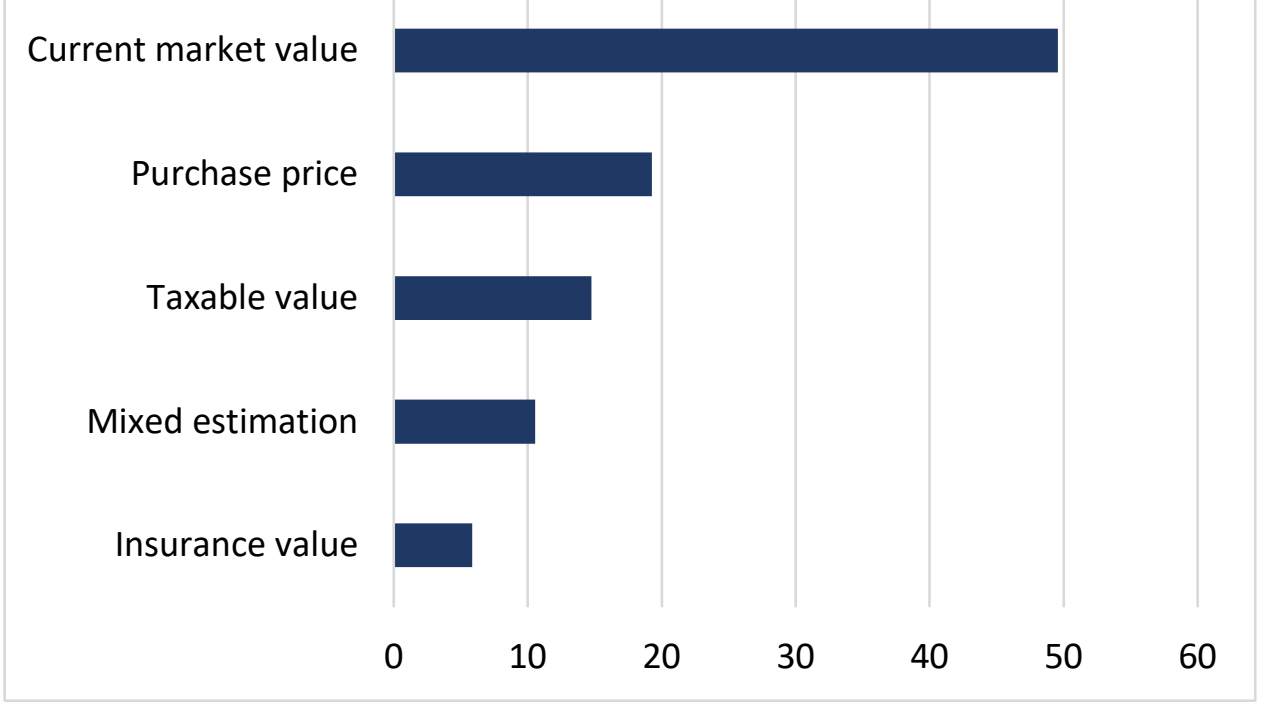

Source: SILC 2015.

Figure 2: Distribution of real estate assets before and after the adjustment to the current market value

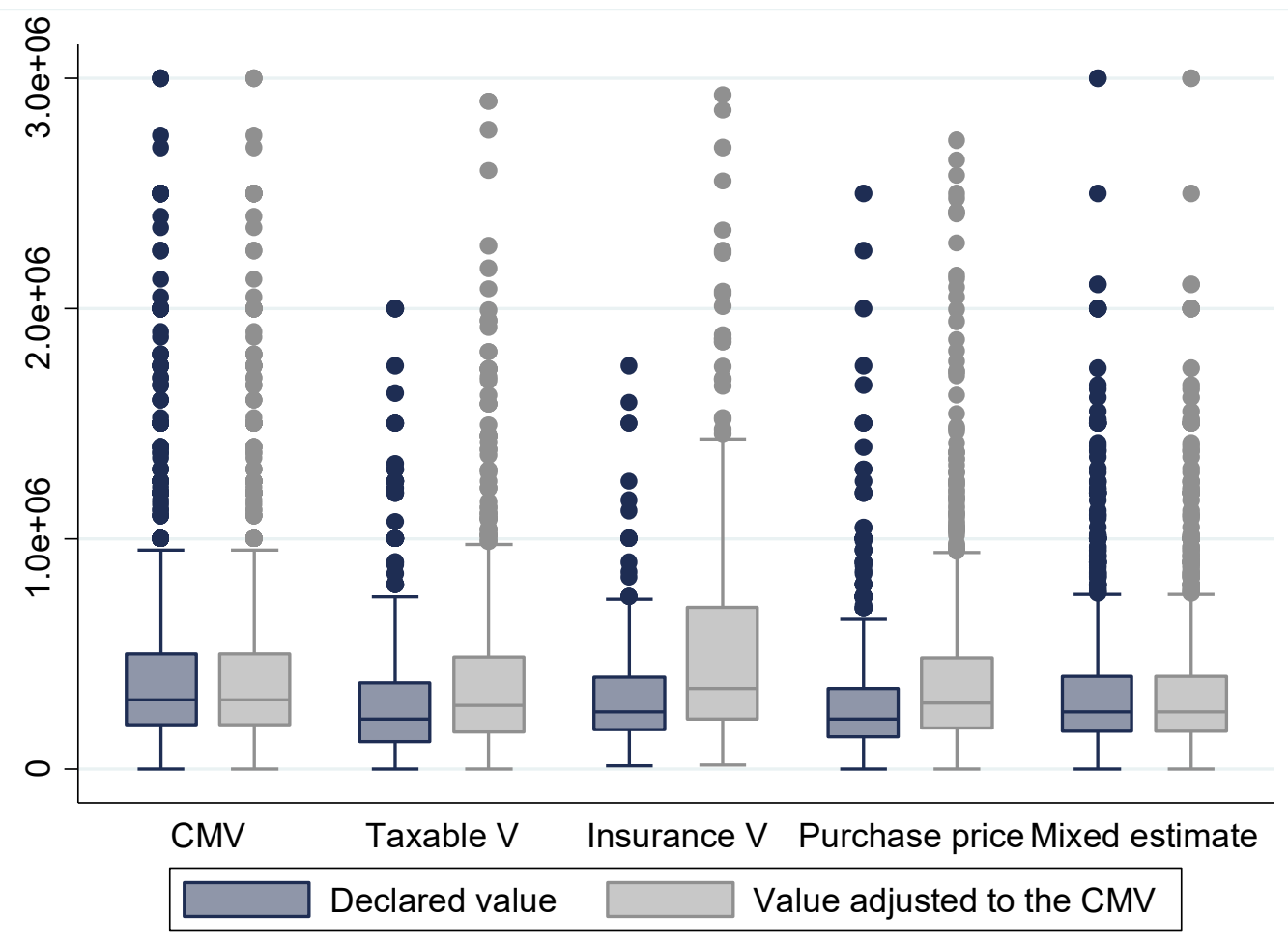

Sources: SILC 2015. Notes: values displayed up to 3,000,000 CHF. Per capita wealth (i.e. household wealth divided by the household size) of the household head with household weights multiplied by the household size. CMV refers to the current market value. 
Figure 3: Housing wealth by age groups, comparison of CH-SILC and SHARE, averages and percentiles
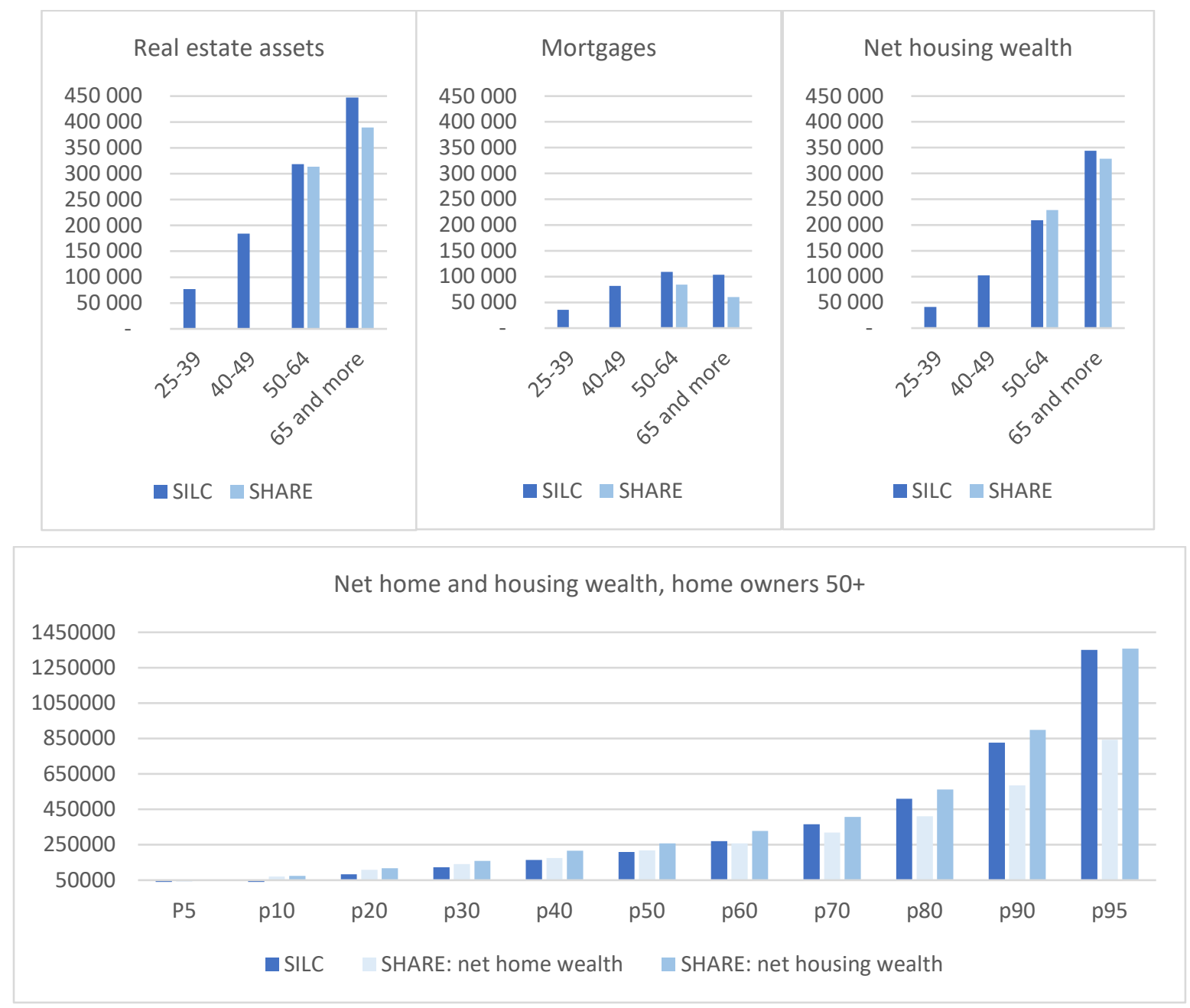

Sources: CH-SILC 2015, SHARE 2015. Notes: net housing wealth in CH-SILC is based on adjusted values.

Per capita wealth of the household head with household weights multiplied by the household size. 
Figure 4: Housing wealth by age groups, comparison of CH-SILC, SHARE and the SHP

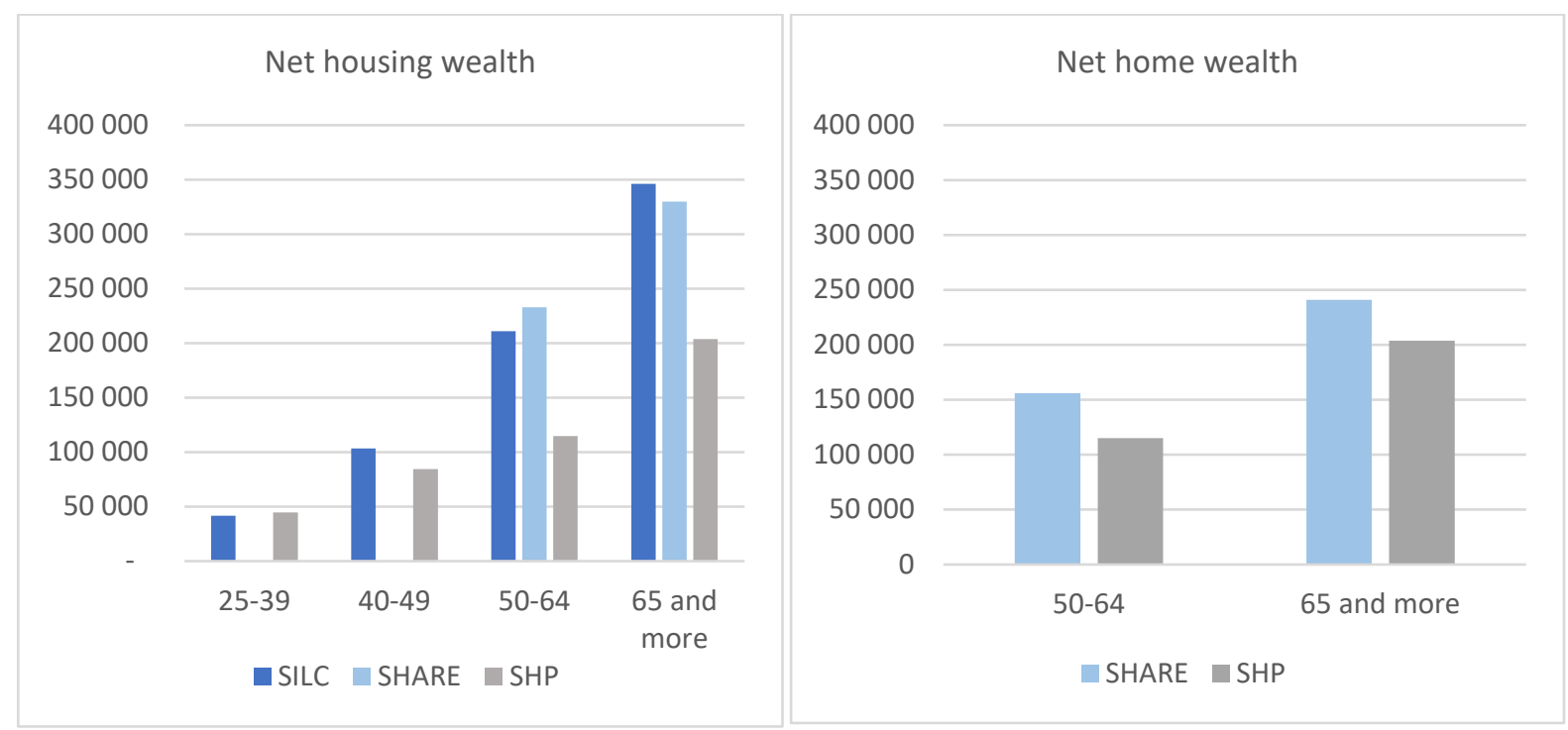

Sources: CH-SILC 2015, SHARE 2015, SHP 2016. Notes: net housing wealth in CH-SILC is based on adjusted values. Values of net housing wealth have been bottom-coded to 0 in CH-SILC and SHARE for the comparison with the SHP, which has been top-coded at the $99.75 \%$ for the same reason. Per capita wealth of the household head with household weights multiplied by the household size.

Figure 5: Mean wealth components by age groups, comparison of CH-SILC and SHARE

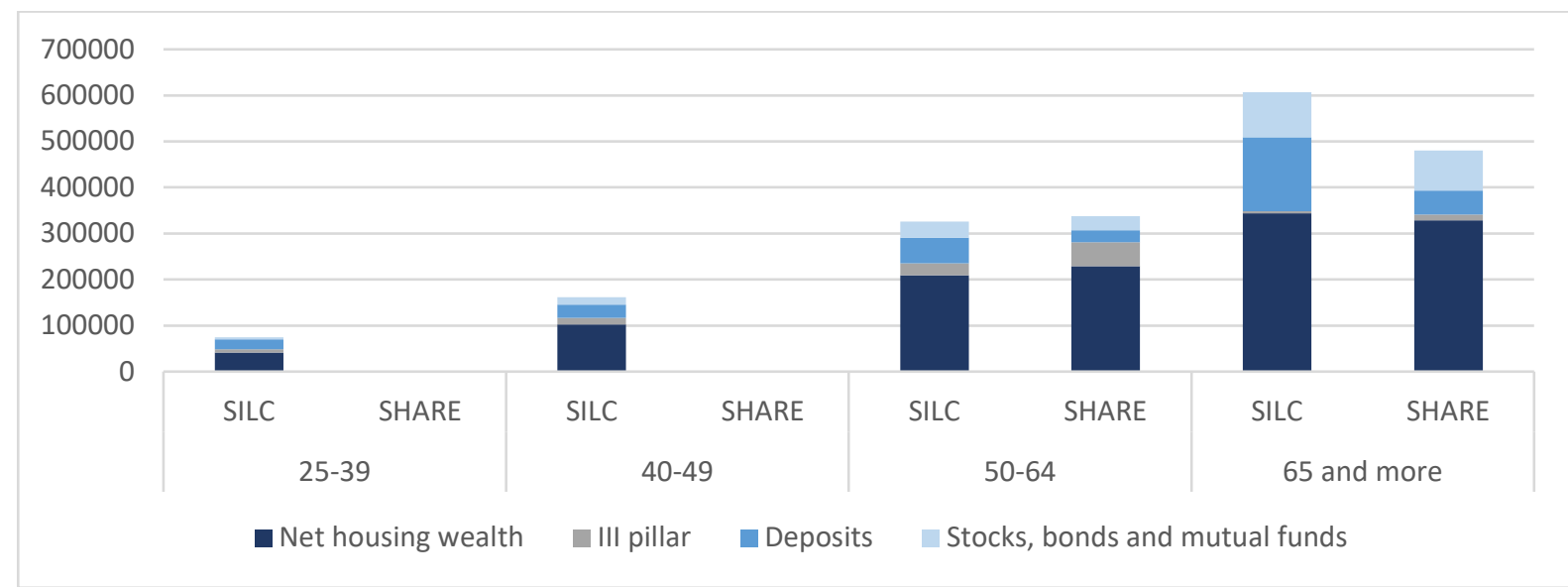

Sources: CH-SILC 2015, SHARE 2015. Notes: net housing wealth is based on adjusted values in CH-SILC. Per capita wealth of the household head with household weights multiplied by the household size. 
Figure 6: Box plots of wealth components among 50+ in CH-SILC and SHARE

a) SILC

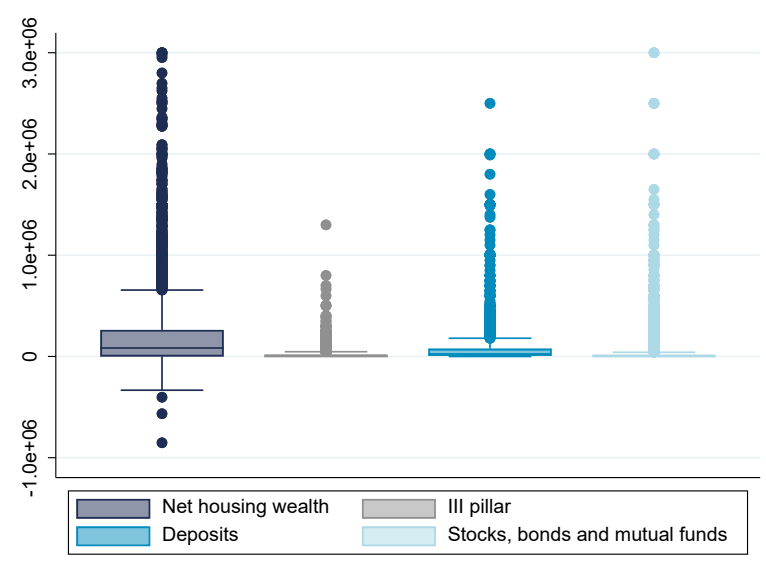

b) SHARE

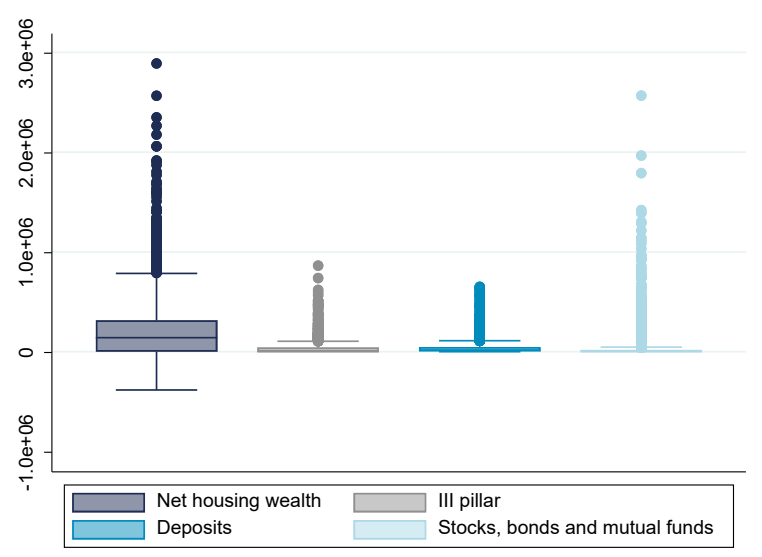

Sources: CH-SILC 2015. Notes: values displayed up to 3,000,000 CHF. Net housing wealth is based on adjusted values. Per capita wealth of the household head with household weights multiplied by the household size. 
Table 1: Variables on housing wealth and pension wealth in the SHP, CH-SILC and SHARE

\begin{tabular}{|c|c|c|c|}
\hline Survey & Variable & $\begin{array}{l}\text { (Value) / Level / } \\
\text { Number of } \\
\text { questions }^{33}\end{array}$ & Question wording \\
\hline \multirow[t]{3}{*}{ SHP } & $\begin{array}{l}\text { Net home wealth } \\
\text { (primary residence) }\end{array}$ & $\begin{array}{l}\text { Current market value } \\
\text { the/ Household level / } 1 \\
\text { question }\end{array}$ & $\begin{array}{l}\text { How much money would } \\
\text { you get if you sold the } \\
\text { house or flat you are living } \\
\text { in, after the deduction of the } \\
\text { amount needed to } \\
\text { reimburse the mortgage } \\
\text { and other loans? }\end{array}$ \\
\hline & $\begin{array}{l}\text { Other wealth (including } \\
\text { financial wealth and } \\
\text { other real estate) }\end{array}$ & $\begin{array}{l}\text { Household level / } 1 \\
\text { question }\end{array}$ & $\begin{array}{l}\text { What is value of your } \\
\text { household assets including } \\
\text { real estate assets, savings, } \\
\text { stocks and bonds, after the } \\
\text { deduction of all your } \\
\text { potential debts? }\end{array}$ \\
\hline & 3rd pillar & $\begin{array}{l}\text { Household level / } 1 \\
\text { question }\end{array}$ & $\begin{array}{l}\text { Do you or any other } \\
\text { member of your household } \\
\text { save in a "3rd pillar" } \\
\text { pension fund? }\end{array}$ \\
\hline \multirow[t]{3}{*}{$\mathrm{CH}-\mathrm{SILC}^{34}$} & Real estate assets & $\begin{array}{l}\text { If possible, current } \\
\text { market value, otherwise } \\
\text { taxable value, insurance } \\
\text { value or purchase price / } \\
\text { Household level / } 1 \\
\text { question }\end{array}$ & $\begin{array}{l}\text { In your opinion, what would } \\
\text { be the value of your real } \\
\text { estate assets (houses and } \\
\text { land) including your main } \\
\text { property and without the } \\
\text { deduction of mortgages? }\end{array}$ \\
\hline & Mortgage & $\begin{array}{l}\text { Amount still to pay on } \\
\text { mortgage / Household } \\
\text { level / } 1 \text { question }\end{array}$ & $\begin{array}{l}\text { Can you indicate the total } \\
\text { value of your mortgages? }\end{array}$ \\
\hline & Financial wealth & $\begin{array}{l}\text { Household level / } 2 \\
\text { questions }\end{array}$ & $\begin{array}{l}\text { Can you indicate the } \\
\text { balance of your bank or } \\
\text { postal accounts? }\end{array}$ \\
\hline
\end{tabular}

${ }^{33}$ The number of questions for the value of a certain component is calculated after possible filter questions, such as questions on whether the respondent holds this component or not. Control questions after the response are not computed in Table 1.

${ }^{34} \mathrm{CH}-\mathrm{SILC} 2015$, questions on wealth have been revised compared to CH-SILC 2011 and will be revised again for CH-SILC 2018 and CH_SILC 2020. 


\begin{tabular}{|c|c|c|c|}
\hline & & & $\begin{array}{l}\text { Can you estimate the total } \\
\text { value of your stocks, bonds } \\
\text { or mutual funds? }\end{array}$ \\
\hline & $3^{\text {rd }}$ pillar $^{35}$ & $\begin{array}{l}\text { Current value / } \\
\text { Individual level / } 1 \\
\text { question (with separate } \\
\text { filters for employed and } \\
\text { self-employed) } \\
+ \\
\text { Future value / Individual } \\
\text { level / } 1 \text { question }\end{array}$ & $\begin{array}{l}\text { Do you have a } 3^{\text {rd }} \text { pillar } \\
\text { private pension account in } \\
\text { an insurance, a bank or a } \\
\text { post office? As a self- } \\
\text { employed, do you have a } \\
2^{\text {nd }} \text { pillar or a } 3^{\text {rd }} \text { pillar } \\
\text { private pension plan in an } \\
\text { insurance, a bank or a post } \\
\text { office? Can you estimate } \\
\text { the total value of all types of } \\
\text { savings in your 3rd pillar? } \\
\text { What amount do you think } \\
\text { you will withdraw from your } \\
\text { 3rd pillar when you finish } \\
\text { contributing? }\end{array}$ \\
\hline SHARE & Main property & $\begin{array}{l}\text { Current market value / } \\
\text { Household level / } 1 \\
\text { question }\end{array}$ & $\begin{array}{l}\text { In your opinion, how much } \\
\text { would you receive if you } \\
\text { sold your property today? }\end{array}$ \\
\hline & Other real estate assets & $\begin{array}{l}\text { Current market value / } \\
\text { Household level / } 1 \\
\text { question for each } \\
\text { property }\end{array}$ & $\begin{array}{l}\text { In your opinion, how much } \\
\text { would [this] property be } \\
\text { worth now if you sold it? }\end{array}$ \\
\hline & $\begin{array}{l}\text { Mortgage on main } \\
\text { property }\end{array}$ & $\begin{array}{l}\text { Amount still to pay on } \\
\text { mortgage or loan / } \\
\text { Household level / } 1 \\
\text { question }\end{array}$ & $\begin{array}{l}\text { How much do you or your } \\
\text { husband/wife/partner still } \\
\text { have to pay on your } \\
\text { mortgages or loans, } \\
\text { excluding interest? }\end{array}$ \\
\hline & Financial wealth & $\begin{array}{l}\text { Current value / } \\
\text { Household level / } 6 \\
\text { questions }\end{array}$ & $\begin{array}{l}\text { How much so you [and your } \\
\text { partner] currently have in } \\
\text { investment funds? } \\
\text { [same questions for] stocks } \\
\text { or shares (listed or unlisted } \\
\text { on the stock market), }\end{array}$ \\
\hline
\end{tabular}

${ }^{35}$ From the French version of the CH-SILC questionnaire: «Retenir les piliers 3a (par ex. compte épargne prévoyance $3 \mathrm{~A}$ ) et les piliers $3 \mathrm{~b}$ (assurance risque décès, assurance vie avec épargne; avec ou sans privilèges fiscaux). Les biens immobiliers (p. ex. Maison) ne sont pas comptés comme 3ème pilier. Pour le pilier 3a, la réponse "montant maximal" indique le montant le plus élevé déductible du revenu imposable. En \{année-1\}, ce montant s'élevait à 6'739.- pour les salariés et à 33'696.- pour les indépendants sans 2ème pilier. Faire confirmer le montant par la personne. Dans le pilier 3b, il n'y aucune limite de montant. » 


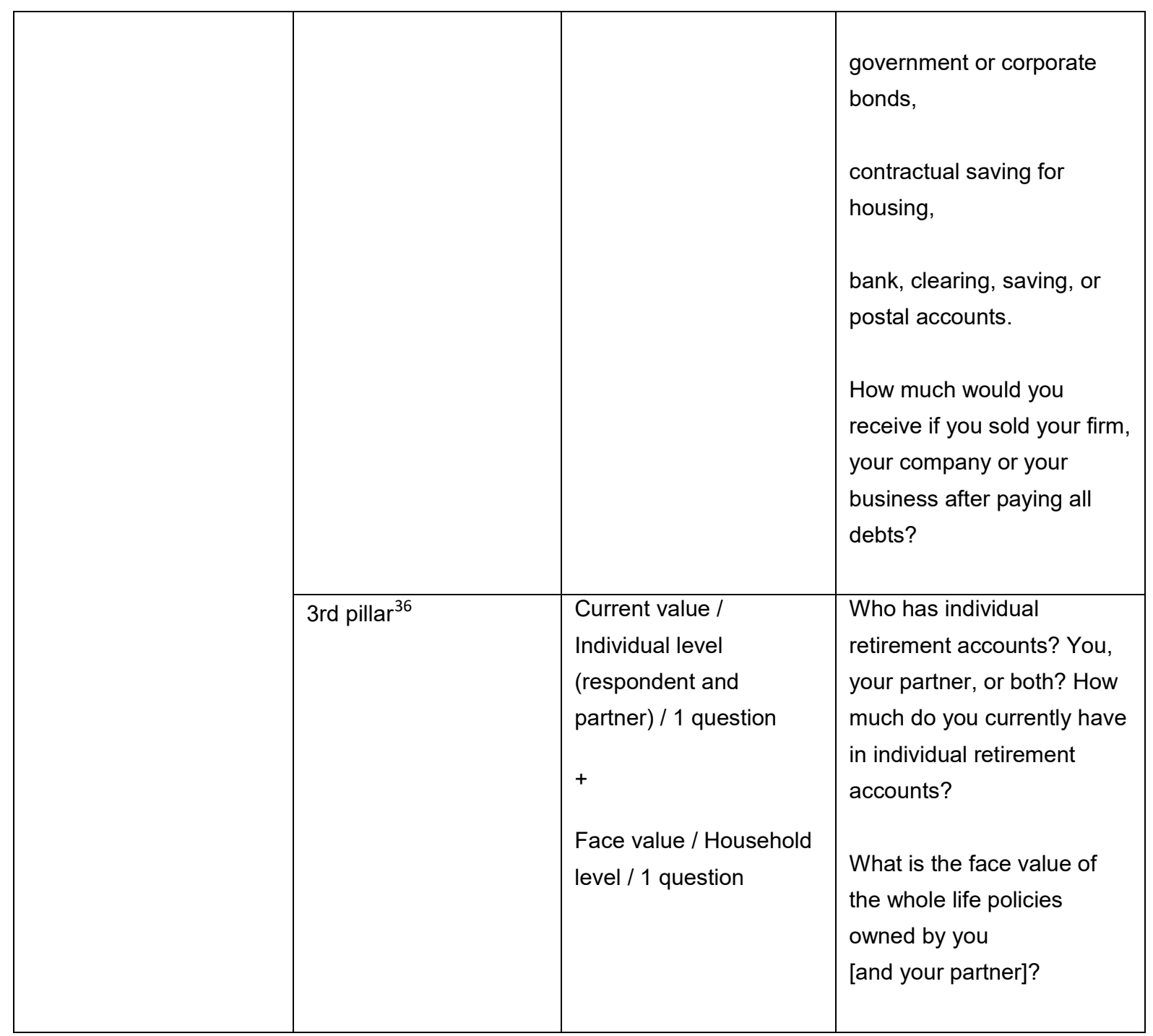

${ }^{36}$ From the French version of the Swiss SHARE questionnaire : «Par compte de retraite privé on entend la prévoyance effectuée dans le cadre du 3ème pilier. Un compte de retraite privé (i.e., le 3ème pilier) est un plan d'épargne-retraite sur lequel la personne met de l'argent de côté chaque année pour être retiré (partiellement) au moment de la retraite. En Suisse, un plan de retraite privé (i.e., le 3ème pilier) peut être sous forme de compte prévoyance, de fonds de placement ou d'assurance vie. Veuillez prendre en compte TOUTES les formes de 3ème pilier. » 
Table 2: Main identifiable components by survey (SHP, CH-SILC, and SHARE)

\begin{tabular}{|c|c|c|c|c|c|c|c|}
\hline \multirow[b]{2}{*}{ Survey } & \multicolumn{2}{|c|}{ Real assets } & \multicolumn{3}{|c|}{ Financial assets } & \multicolumn{2}{|c|}{ Liabilities } \\
\hline & Real estate & $\begin{array}{l}\text { Valuables/Cons } \\
\text { umer durables }\end{array}$ & Deposits & $\begin{array}{l}\text { Other financial } \\
\text { assets }\end{array}$ & Pensions funds & Mortgages & Loans \\
\hline SHP & $\begin{array}{l}\text { Primary home wealth } \\
\text { (net) }\end{array}$ & - & - & - & $\begin{array}{l}\text { Only presence of the III } \\
\text { pillar }\end{array}$ & - & - \\
\hline $\mathrm{CH}-\mathrm{SILC}$ & Total real estate (gross) & $\begin{array}{c}\text { Cars, jewellery, } \\
\text { art }\end{array}$ & $\begin{array}{l}\text { Bank or postal } \\
\text { accounts }\end{array}$ & $\begin{array}{l}\text { Stocks, bonds or } \\
\text { mutual funds }\end{array}$ & III pillar & Total amount & - \\
\hline SHARE & $\begin{array}{l}\text { Primary home wealth } \\
\text { (gross) and other real } \\
\text { estate (gross) }\end{array}$ & Only cars & $\begin{array}{l}\text { Bank, clearing, } \\
\text { saving, or postal } \\
\text { accounts }\end{array}$ & $\begin{array}{l}\text { Investment funds, } \\
\text { stocks or shares } \\
\text { (listed or unlisted } \\
\text { on the stock } \\
\text { market), } \\
\text { government or } \\
\text { corporate bonds, } \\
\text { contractual savings } \\
\text { for housing, value } \\
\text { of business }\end{array}$ & III pillar & $\begin{array}{l}\text { Only on primary } \\
\text { home wealth }\end{array}$ & Total amount \\
\hline
\end{tabular}

Notes: Green shaded cells indicate compliance with the OECD guidelines on measuring household wealth. 
Table 3: Comparison between CH-SILC 2015 and NA 2014, SHP 2016 and NA 2016, averages

\begin{tabular}{|c|c|c|c|c|c|}
\hline & $\begin{array}{c}\text { Real estate } \\
\text { assets }\end{array}$ & Mortgages & $\begin{array}{c}\text { Net housing } \\
\text { wealth }\end{array}$ & $\begin{array}{c}\text { Financial } \\
\text { wealth }\end{array}$ & Net worth \\
\hline NA 2014 & 220,381 & 89,800 & 130,581 & 137,630 & 288,850 \\
\hline CH-SILC 2015 & 235,216 & 79,309 & 155,907 & 102,763 & 264,897 \\
\hline Ratio CH-SILC/NA & $107 \%$ & $88 \%$ & $119 \%$ & $75 \%$ & $92 \%$ \\
\hline NA 2016 p.c & 225,580 & 93,209 & 132,371 & 139,919 & 294,005 \\
\hline SHP 2016 p.c & - & - & 190,479 & - & 405,834 \\
\hline Ratio SHP/NA & - & - & $144 \%$ & - & $138 \%$ \\
\hline
\end{tabular}

Sources: SNB 2015, 2016; CH-SILC 2015, SHP 2016. Notes: household weights multiplied by the household size provided by the survey are used for survey data. The second pillar is excluded in NA for the calculation of net worth. Real estate assets in CH-SILC are based on adjusted values.

Table 4: Distribution of total net worth, CH-SILC and the SHP

\begin{tabular}{|c|c|c|c|c|c|c|c|c|c|c|}
\hline $\begin{array}{l}\text { CH- } \\
\text { SILC }\end{array}$ & $-762,661$ & 1,033 & 14,325 & 79,000 & 264,897 & 252,107 & 608,865 & 960,000 & $\begin{array}{c}2.650 \\
\text { million }\end{array}$ & $\begin{array}{c}121 \\
\text { million }\end{array}$ \\
\hline SHP & 0 & 0 & 12,500 & 100,000 & 405,834 & 300,000 & 750,000 & $\begin{array}{c}1.3 \\
\text { million }\end{array}$ & $\begin{array}{c}3.614 \\
\text { million }\end{array}$ & $\begin{array}{c}106 \\
\text { million }\end{array}$ \\
\hline
\end{tabular}

Sources CH-SILC 2015, SHP 2016. Notes: Per capita wealth with household weights multiplied by the household size. 